\title{
Determination of penicillin susceptibility of Streptococcus pneumoniae using the polymerase chain reaction
}

\begin{abstract}
Aim-To develop a polymerase chain reaction (PCR) based method to detect penicillin susceptibility in isolates of Streptococcus pneumoniae (SP).

Methods-PCR primers were designed to amplify differential nucleotide sequences of the penicillin-binding protein (PBP) genes $2 b, 2 x$, and $1 a$ in penicillin susceptible and resistant strains of SP. Primers derived from the PBP $2 x$ and $2 b$ genes were designed to amplify products from penicillin susceptible $S$ pneumoniae (PSSP), whereas primers derived from the PBP 1a gene were designed to amplify gene sequences of penicillin resistant $S$ pneumoniae (PRSP).

Results-Two hundred and thirty clinical isolates of SP from the USA, UK, Kenya, Romania, and the Kingdom of Saudi Arabia were tested. Of the isolates, 116 were penicillin susceptible, 65 were intermediately resistant, and 49 were highly resistant. PCR identified 108 (93\%) of 116 of PSSP isolates, 55 (85\%) of 65 intermediately resistant isolates, and all of the 49 highly resistant isolates of SP. The susceptibility of $16(7 \%)$ isolates could not be determined using PCR. All of these 16 isolates had a minimum inhibitory concentration (MIC) of penicillin $\leq \mathbf{1} \mathrm{mg} / \mathrm{l}$. None of the highly resistant isolates was identified as penicillin susceptible by PCR, although two of the isolates with intermediate resistance $(\mathrm{MIC}=0.125 \mathrm{mg} / \mathrm{l})$ were. Conclusion-Using primers that differentially identify the genotypes of susceptible and resistant strains of SP, PCR provides a rapid method for determining the penicillin susceptibility of SP isolates and could potentially be used for testing clinical samples.

(F Clin Pathol: Mol Pathol 1997;50:45-50)
\end{abstract}

Keywords: Streptococcus pneumoniae; polymerase chain reaction; penicillin-binding proteins.

Baylor College of Medicine, Infectious Diseases MC3-2371, Texas Children's Hospital, Fannin Houston, Texas 77030 , USA

E O'Mason Jnr

Correspondence to: Dr H Jalal.

Accepted for publication 14 November 1996

deaths globally each year, ${ }^{1}$ and penicillin remains the antibiotic of choice for most serious infections caused by Streptococcus pneumoniae (SP). However, penicillin resistant $S$ pneumoniae (PRSP) have spread to almost all parts of the world, and the prevalence of these resistant strains in any particular country is largely dependent on antibiotic pressure and number of children under 14 years of age. ${ }^{2}$ Prevalence is low in the UK and Italy (2-3\%) and is high in Spain, Hungary, Romania, Turkey, South Korea, South Africa, and some parts of North America (40-50\%). ${ }^{2}$ Resistance to newer cephalosporins, such as cefotaxime and ceftriaxone, is increasing, ${ }^{34}$ and prevalences of cefotaxime resistant SP of $9 \%$ and $6 \%$ have been reported recently in Atlanta (USA) ${ }^{5}$ and Barcelona (Spain), ${ }^{6}$ respectively. PRSP are also frequently resistant to non- $\beta$-lactam antibiotics, often having raised minimum inhibitory concentration (MIC) values for cotrimoxazole, tetracycline, chloramphenicol, erythromycin, and fluoroquinolones. ${ }^{7-9}$

PCR has been used extensively for the diagnosis of microbial infections as well as characterisation of antimicrobial resistance genesfor example, rifampicin and isoniazid resistance in Mycobacterium tuberculosis, ${ }^{10}{ }^{11}$ glycopeptide and fluoroquinolone resistance in Enterococcus spp. ${ }^{12} 13$ ampicillin resistance in Haemophilus influenzae,${ }^{14}$ methicillin resistance in Staphylococcus aureus, ${ }^{15}$ amikacin resistance in Acinetobacter spp., ${ }^{16}$ and quinolone resistance in Shigella dysenteriae. ${ }^{17}$ Resistance to penicillin and other $\beta$-lactam antibiotics in SP is caused by the production of five altered high molecular weight penicillin-binding proteins (PBP), $1 \mathrm{a}, 1 \mathrm{~b}, 2 \mathrm{x}, 2 \mathrm{a}$, and $2 \mathrm{~b}$, with reduced $\beta$-lactam affinity. ${ }^{18-21}$ The nucleotide sequences of genes coding for the native and altered PBP $(2 b, 2 x$, and 1a) of both PRSP and penicillin susceptible $S$ pneumoniae (PSSP) have been reported. ${ }^{22-24}$ PCR primers were designed to amplify the differential nucleotide sequences of these genes in penicillin susceptible and resistant strains of SP. Using primers derived from the pneumolysin, autolysin, and DNA polymerase I genes, and the $16 \mathrm{~S}-23 \mathrm{~S}$ spacer ribosomal region, PCR has been used successfully to diagnose pneumococcal infection in blood, ${ }^{25-29}$ sputum, ${ }^{30}$ cerebrospinal fluid, ${ }^{31}$ and primary culture isolates. ${ }^{32}$ We describe the use of PCR to differentiate between the penicillin susceptible and resistant genotypes of SP. Ubukata et $a l^{33}$ have described a similar approach to detect the autolysin and PBP $2 b$ genes of SP, and we have extended this approach to include the PBP $2 x$ and 1 a genes.

\section{Methods}

BACTERIAL STRAINS

Clinical isolates of SP were obtained from the Bacteriology Department, Public Health Laboratory, Bristol, UK (including five or 
Table 1 Primers sequences

\begin{tabular}{llll}
\hline Code & Gene & Location $(b p)$ & Sequence (5'-3') \\
\hline SP $_{1}$ & Pneumolysin & 1378 & TCTTGACTCCTAAGGCTTGG \\
SP $_{2}$ & Pneumolysin & 1565 & AATCGTCCGCTTACGCACTA \\
$2 \mathrm{x}_{1}$ & PBP 2x & 1669 & GTCATGCTGGAGCCTAAATT \\
$2 \mathrm{x}_{2}$ & PBP 2x & 1946 & AACCCGACTAGATAACCACC \\
$2 \mathrm{~b}_{1}$ & PBP 2b & 694 & ACTCAGGCTTACGGTTCATT \\
$2 \mathrm{~b}_{4}$ & PBP 2b & 1053 & ACGAGGAGCCACACGAACAC \\
$1 \mathrm{a} \mathrm{FP}$ & PBP 1a & 1315 & AGGTCGGTCCTAGATAGAGCT \\
$1 \mathrm{a} \mathrm{RP}$ & PBP 1a & 1738 & GAGCTACATAGCCAGTGT/CTC \\
\hline
\end{tabular}

$\mathrm{bp}=$ base pairs. hours. GeneReleaser (20 $\mu \mathrm{l}$; Cambio, Cambridge, UK) was mixed with one to five bacterial colonies in a $500 \mu \mathrm{l}$ Eppendorf tube. DNA templates for PCR were prepared as described by the manufacturer and $5 \mu \mathrm{l}$ GeneReleaser product was used in each PCR reaction. To ascertain the sensitivity of each primer set, Mueller-Hinton broth containing 5\% horse serum was inoculated with SP and incubated at $37^{\circ} \mathrm{C}$ for four hours. Bacterial cells were centrifuged at $12000 \times g$ for one minute, the supernatant was discarded, and the bacterial pellet was washed three times with $1 \times \mathrm{TE}$ buffer (10 mM Tris, EDTA, pH 7.6). The bacterial pellet was then re-suspended in $200 \mu \mathrm{l}$ $1 \times$ TE buffer. Tenfold dilutions were made from this suspension in TE buffer for PCR, and in Mueller-Hinton broth for the determination of colony forming units (CFUs) using a modified Miles and Misra method. ${ }^{36}$ DNA from these dilutions was prepared as described earlier.

SELECTION OF PRIMERS

Sequences of PBP $2 x, 2 b$, and $1 \mathrm{a}$ genes from PSSP and PRSP strains were compared and differential sequences were identified. The PCR and Oligo Primer Design program (Scientific Educational Software, USA) was used to design primers from the PBP genes and the pneumolysin gene. Primers derived from . the PBP $2 \mathrm{x}$ and $2 \mathrm{~b}$ genes were designed to produce amplification products from PSSP, whereas primers from the PBP 1a gene were designed to amplify PRSP gene sequences. Primers derived from sequences encoding the penicillin binding domain of PBPs were used to amplify $\mathrm{PBP} 2 \mathrm{~b}, 2 \mathrm{x}$, and $1 \mathrm{a}$ genes. Many regions of the PBP $2 b$ genes of penicillin sensitive isolates of $S$ mitis and SP are highly homologous, ${ }^{37}$ and, therefore, at least one primer for amplifying the PSSP PBP $2 \mathrm{~b}$ gene was derived from a region of low DNA homology between these strains to increase the specificity of the PCR. The location of these primers in the genes and their sequences are shown in table 1 .

POLYMERASE CHAIN REACTION

The PCR reaction mixture comprised $10 \mathrm{mM}$ Tris- $\mathrm{HCl}\left(\mathrm{pH}\right.$ 9.0) $1.5 \mathrm{mM} \mathrm{MgCl}_{2}, 50 \mathrm{mM}$ $\mathrm{KCl}, 0.01 \%$ gelatin, $0.01 \%$ Triton X-100, స $20 \mu \mathrm{M}$ each dNTP, $0.1 \mu \mathrm{M}$ of each of four primers, 0.25 units SuperTaq polymerase (HT Biotechnology Ltd, Cambridge, UK), and $5 \mu \mathrm{l}$ DNA extract prepared using GeneReleaser. The primer combinations were SP1 and SP2 derived from the pneumolysin gene with $2 \mathrm{x}_{1}$ and $2 \mathrm{x}_{2}$ derived from the PBP $2 \mathrm{x}$ gene, or $2 \mathrm{~b}_{1}$ and $2 b_{4}$ derived from the PBP $2 b$ gene, or $1 \mathrm{a}$ FP and 1a RP derived from the PBP 1 a gene. A hot start PCR method was used-ingredients for amplification were mixed with DNA at $75^{\circ} \mathrm{C}$. Before the start of cycling, DNA was denatured for three minutes at $94^{\circ} \mathrm{C}$. PCR conditions were as follows: $94^{\circ} \mathrm{C}$ for 30 seconds, $60^{\circ} \mathrm{C}$ for 30 seconds and at $72^{\circ} \mathrm{C}$ for two minutes for 35 cycles in three different units of an OmniGene Hybaid Thermal Cycler or a Hybaid Thermal Reactor. After 35 cycles
Bacteria were grown on blood agar base (Columbia CM 331, Unipath) containing 5\% horse blood and incubated in air at $37^{\circ} \mathrm{C}$ for 18 . .}

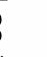

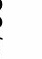

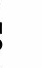
$\vec{t}$ .

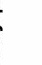


A

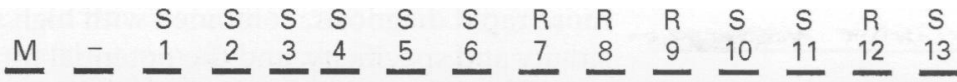

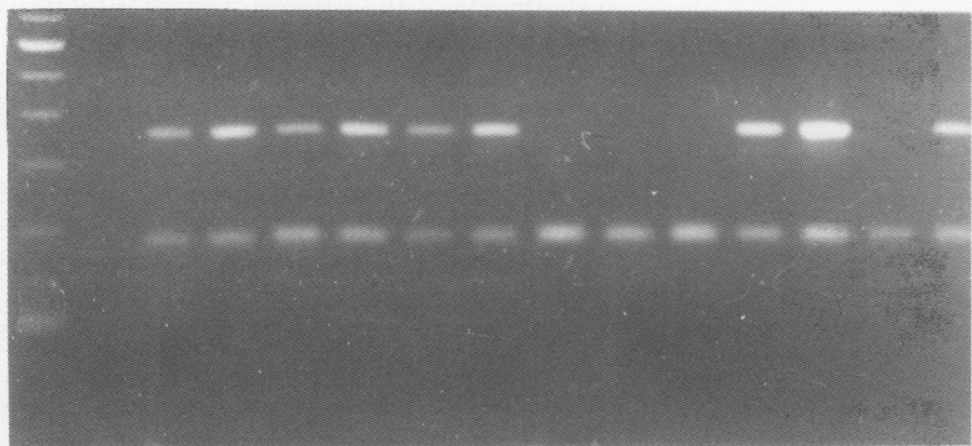

B
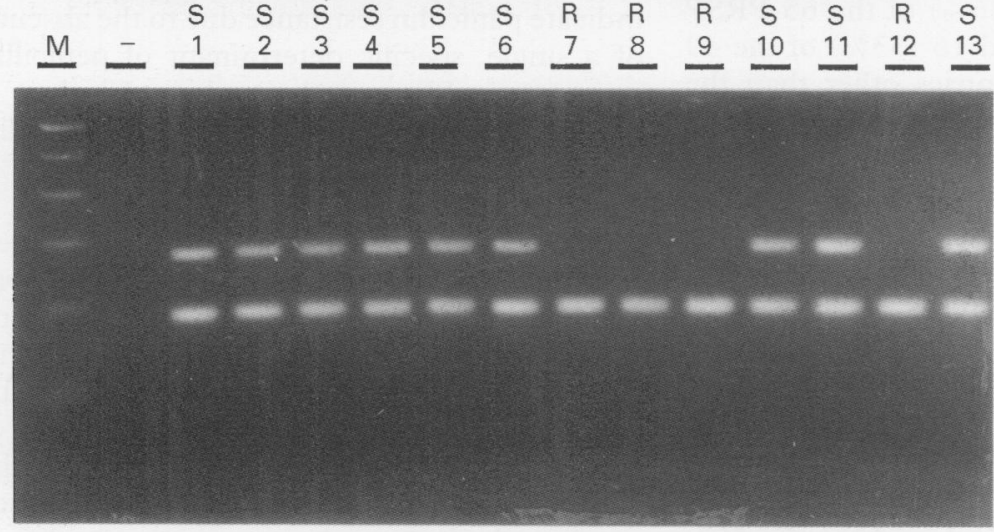

C
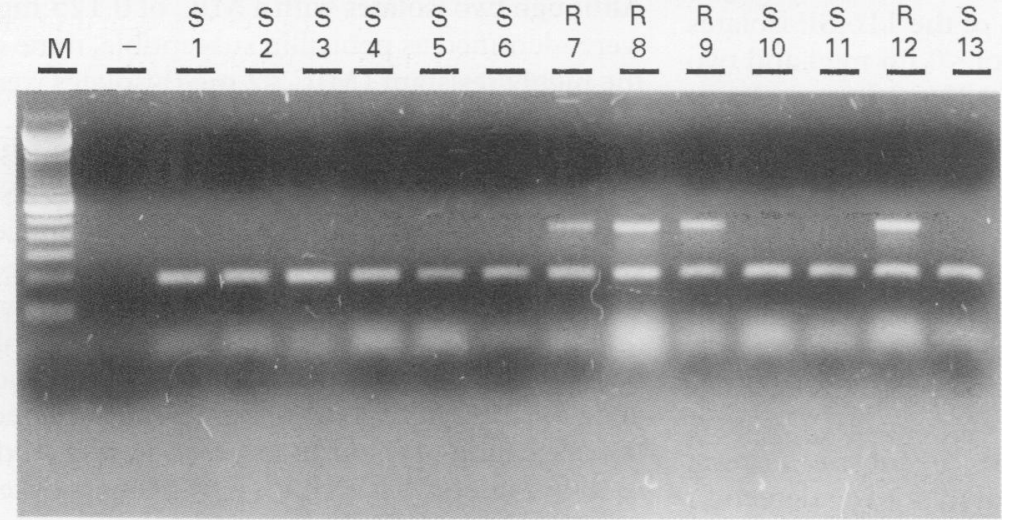

Figure 1 Agarose gel electrophoresis of PCR products amplified using primers derived from the $P B P 2 b$ and pneumolysin genes $(A), P B P 2 x$ and pneumolysin genes $(B)$ and $P B P 1 a$ and pneumolysin genes $(C)$. The sizes of the PCR products using primers for the $P B P 2 b, 2 x, 1 a$, and pneumolysin genes are 359, 277, 423, and 187 base pairs (bp), respectively. Lane $M$, marker (100 bp ladder); lane -, negative control (contained all ingredients for the PCR reaction except DNA which was replaced by analar water); lanes $1-13$, clinical isolates of $S P ; S$, penicillin susceptible $S P ; R$, penicillin resistant $S P$.

of amplification, tubes were heated at $72^{\circ} \mathrm{C}$ for seven minutes. One negative and two positive controls were included in each PCR run. In the negative control, DNA was replaced by an equal amount of injection water (Braun, Bucks, UK). Two clinical isolates of SP with MICs of 0.03 and $1.0 \mathrm{mg} / \mathrm{l}$ were used as positive controls. DNA was extracted, amplification reactions prepared, and PCR products analysed in three different rooms with designated equipment for each room. Aerogard tips with a barrier (Alpha Laboratories Ltd, UK) were used throughout the experiments to prevent aerosol contamination of pipettes. PCR products were electrophoresed on $2 \%$ agarose gels containing $0.005 \%$ ethidium bromide using $1 \times$ Tris borate buffer $(0.89 \mathrm{mM}$ Tris borate,
$0.89 \mathrm{mM}$ boric acid, $0.2 \mathrm{mM}$ EDTA, $\mathrm{pH} 8.3$ ), and bands visualised with ultraviolet transillumination.

\section{Results}

SENSITIVITY, SPECIFICITY, REPRODUCIBILITY, AND RAPIDITY OF THE METHOD

A multiplex format was used for PCR, using a pair of primers designed to amplify the pneumolysin gene, and a pair of primers derived from one of the three PBP genes, $2 \mathrm{x}$, $2 \mathrm{~b}$, and 1a. DNA from 10 CFUs of PSSP was detected using primers derived from the pneumolysin and PBP $2 \mathrm{~b}$ genes, from 40 CFUs using primers derived from the pneumolysin and PBP $2 x$ genes, and from 300 CFUs using primers derived from the pneumolysin and PBP 1a genes. Primers derived from the pneumolysin and PBP 2b, 2x, and 1a genes did not amplify DNA from any of the 22 isolates of Streptococcus spp. or the six isolates of $E$ faecalis. The PCR was applied three times to each clinical isolate of SP by five investigators, using two different thermal cyclers, over a period of three years with reproducible results. The positive and negative controls in each run produced the expected results. The penicillin susceptible or resistant genotypes of 10 primary culture isolates of SP could be identified within about six hours. A typical experiment contained amplification reactions for 10 clinical isolates, one negative and two positive controls. On average, it took one and half hours to extract the DNA and prepare amplification reactions (13 reactions for each of the PBP $2 b, 2 x$, and $1 \mathrm{a}$ genes), three hours for amplification, and one and a half hours for gel electrophoresis.

DETECTION OF THE PENICILLIN SUSCEPTIBLE GENOTYPE USING PRIMERS FROM THE PBP $2 b$ GENE

The PCR using primers designed to detect the PBP $2 \mathrm{~b}$ gene of PSSP (fig 1A) amplified DNA from $116(100 \%)$ PSSP isolates and $10(8.8 \%)$ of the 114 PRSP isolates. The MIC of penicillin for these 10 PRSP isolates was $\leq 1.0 \mathrm{mg} / 1$. Eight of these were identified as PRSP and two as PSSP using primers derived from the PBP $2 x$ gene. The origin of isolates which gave false positive or negative reactions was as follows: two from the UK, three from Kenya, two from Romania, and three from the USA.

DETECTION OF THE PENICILLIN SUSCEPTIBLE GENOTYPE USING PRIMERS FROM THE PBP $2 \mathrm{x}$ GENE

The PCR using primers designed to detect the PBP 2x gene of PSSP (fig 1B) amplified DNA from $110(94.8 \%)$ of the 116 PSSP isolates and four $(3.5 \%)$ of the 114 PRSP isolates. The MIC of penicillin for these four PRSP isolates was $\leq 0.5 \mathrm{mg} / \mathrm{l}$. The origin of isolates which gave false positive or negative reactions was as follows: one from Kenya, five from Romania, and four from the USA. Two of these isolates also gave a false positive reaction with primers derived from the PBP $2 b$ gene. 
Table 2 Summary of PCR results

\begin{tabular}{lllcc}
\hline \multirow{2}{*}{$\begin{array}{l}\text { Penicillin } \\
\text { MIC }(\mathrm{mg} / \mathrm{l})\end{array}$} & $\begin{array}{l}\text { Number } \\
\text { of isolates }\end{array}$ & \multicolumn{2}{c}{ Results of PCR with different primer combinations } \\
\cline { 3 - 5 } & & Combination 1 & Combination 2 & Combinations 1 and 2 \\
\hline$<0.06$ & 116 & 116 & 110 & 108 \\
$0.125-1$ & 65 & 10 & 4 & 2 \\
$\geq 2$ & 49 & 0 & 0 & 0
\end{tabular}

Combination $1=2 \mathrm{~b}_{1}+2 \mathrm{~b}_{4}, \mathrm{SP}_{1}+\mathrm{SP}_{2}$; combination $2=2 \mathrm{x}_{1}+2 \mathrm{x}_{2}, \mathrm{SP}_{1}+\mathrm{SP}_{2}$

DETECTION OF THE PENICILLIN RESISTANT GENOTYPE USING PRIMERS FROM THE PBP 1a GENE

The PCR using primers designed to detect the PBP 1a gene of PRSP (fig 1C) amplified DNA from $72(63 \%)$ of the 114 PRSP isolates. These 72 isolates include $56(86 \%)$ of the 65 PRSP isolates from the UK and 16 (33\%) of the 49 PRSP isolates from countries other than the UK. None of the 116 PSSP isolates gave an amplification product. The results of PCR with different sets of primers are shown in table 2 .

DIAGNOSTIC CRITERIA FOR THE DETECTION OF PENICILLIN SUSCEPTIBILITY OF SP USING PCR Isolates were classified as follows: penicillin susceptible if amplification products were produced with both the $2 \mathrm{~b}$ and $2 \mathrm{x}$ primer sets; unconfirmed if amplification products were produced with one of the primer sets; and resistant if no amplification products were produced with any of the primer sets. According to these criteria, $108(93 \%)$ of the 116 SP isolates with a MIC of penicillin of $<0.06 \mathrm{mg} / \mathrm{l}$ and two isolates with a MIC of $0.125 \mathrm{mg} / \mathrm{l}$ were identified as susceptible to penicillin. Fifty five $(85 \%)$ of the 65 isolates with a MIC of penicillin between 0.125 and $1 \mathrm{mg} / \mathrm{l}$, and all 49 isolates with a MIC $\geq 2 \mathrm{mg} / \mathrm{l}$ were identified as penicillin resistant. The penicillin susceptibility of 16 isolates (eight with a MIC $<0.06 \mathrm{mg} / \mathrm{l}$ and eight with a MIC between 0.125 and $1 \mathrm{mg} / \mathrm{l}$ ) could not be identified using PCR. The PCR using primers derived from the PBP 1 a gene was excluded from the diagnostic criteria because of its poor sensitivity for the detection of the penicillin resistant genotype of SP isolates. The sensitivity of this assay for the detection of the penicillin susceptible or resistant genotypes varies with the country of origin of the isolates, detecting $157(98.7 \%)$ of the $159 \mathrm{SP}$ isolates from the UK, $38(88.3 \%)$ of the 43 from the USA, six (60\%) of the 10 from Kenya, eight $(53.3 \%)$ of the 15 from Romania, and all three $(100 \%)$ from the KSA.

\section{Discussion}

Early detection of infection with the PRSP is essential both to ensure effective treatment and early implementation of measures for the prevention of secondary cases. Methods of detection based on culture take several days and have poor sensitivity in patients treated with antibiotics. Diagnosis of pneumococcal infections by antigen detection in clinical samples is rapid but this approach lacks sensitivity as well as specificity. ${ }^{38} \mathrm{~A}$ number of reports have described the identification of SP DNA in clinical samples using PCR, ${ }^{25-31}$ and have highlighted the advantages of PCR compared with traditional culture methods. These include a more rapid diagnosis, combined with high sensitivity and specificity, and the potential for use in diagnosis of the pneumococcal infections in patients pre-treated with antibiotics.

Mosaic PBP 2b, 2x, and 1a genes alone are sufficient to attain high level penicillin resistance in SP. ${ }^{39}$ Nucleotide sequences of PBP $2 x$, $2 \mathrm{~b}$, and $1 \mathrm{a}$ genes vary considerably among strains of PSSP and PRSP. The precise role of this sequence variation in development of penicillin resistance is not clear, but this study and recent work of Ubukata $e t a l^{3}$ show that some of these differential nucleotide sequences can act as markers for penicillin susceptibility. We chose to use negative PCR amplification to indicate penicillin resistance due to the absence of a single, specific determinant of penicillin resistance in SP, as in the study by Ubukata et $a{ }^{33}$ The sensitivity of their assay for determining penicillin susceptibility of SP was $72.1 \%$, when the target of PCR was class A and B mutations of the PRSP PBP 2b gene compared with $98.9 \%$ when the PSSP PBP $2 b$ gene was amplified. Targeting more than one PBP gene of PSSP increased the specificity of this technique. We propose that PCR could be extremely useful in the early identification of penicillin resistance in a sample or isolate, if the PBP $2 b$ and $2 x$ primer sets fail to give a product but the pneumolysin gene is amplified. Although two isolates with a MIC of $0.125 \mathrm{mg} / 1$ were identified as penicillin susceptible, none of the highly resistant (MIC $\leq 2 \mathrm{mg} / \mathrm{l})$ isolates were classified as penicillin susceptible using PCR.

The primers designed to amplify PSSP PBP $2 x$ and $2 b$ genes distinguished between PSSP and PRSP strains from a number of countries with variable success. Differences in the detection of the penicillin susceptible genotype from different geographical regions is presumably because of small clonal variations which do not alter the affinity of PBP to penicillin but affect the annealing of the primers used in this study to their targets. A search for new primers based on variations of PBP genes in countries other than the UK is under way to improve the sensitivity of this assay for these countries. As the number of isolates of SP from countries other than the UK was small, we have not attempted to compare the sensitivity of this method for determination of SP penicillin susceptibility from different countries. The primers designed to amplify the PRSP PBP 1 a gene were highly specific but lacked sensitivity, and were excluded from the diagnostic criteria. The sensitivity of the PBP 1a primer set was far higher for SP isolates from the UK $(86 \%)$ compared with isolates from other parts of the world (33\%). This is probably because of a dominant clone or few related clones with little variation in the PRSP PBP 1a gene in the UK. The sensitivity of PCR for determination of penicillin susceptibility of SP was low $(85 \%)$ for intermediately resistant strains compared with PSSP (93\%) and highly resistant SP strains $(100 \%)$. Acquisition of resistance in SP is a stepwise process. The PBP genes of PSSP have very few mutations, whereas the PBP genes of highly resistant SP have a large number of 
mutations, ${ }^{23-25}$ with intermediately resistant SP falling somewhere in between. It is, therefore, not surprising that this study was more successful in determining the penicillin susceptibility of PSSP and highly resistant SP rather than intermediately resistant SP. However, using this PCR method, we were unable to differentiate between moderately and highly resistant SP. We intend to design more sensitive primers for the PBP 1a gene of PSSP and extra primers for additional PBP genes in an attempt to differentiate between moderately and highly resistant strains of SP.

In conclusion, the assay described here is simple, reproducible, sensitive, and rapid. The penicillin susceptibility of primary culture isolates of SP can be determined within six hours and requires just two PCR assays under the same amplification conditions using 10-40 CFU DNA/reaction. We deliberately avoided using nested $\mathrm{PCR}^{25}$ or probes ${ }^{26-28}{ }^{30}$ to keep the test simple and rapid, which are important considerations if the test is to be applied in clinical practice. By use of the hot start method and freshly prepared DNA from overnight bacterial growth, DNA degradation or contaminination were not detected by gel electrophoresis. Each PCR assay on each isolate of SP was repeated three times to test the reproducibility of the method. Equivocal results were unusual and were generally associated with degradation of DNA following storage. As results were completely reproducible, one series of amplification is thought to be sufficient for determination of penicillin susceptibility of SP. The primers used in this study were highly specific for pneumococci, the transfer of PBP gene sequences among SP and the related viridans group of streptococci is well characterised, but we did not observe any cross reaction in this study. The multiplex PCR format could be used to determine the penicillin susceptibility of SP in clinical samples from sterile sites, such as blood or cerebrospinal fluid, in addition to primary culture isolates.

We wish to thank Dr Alan Johnson, Professor David C E Speller and Dr T G Coffey for providing bacterial strains; Jennifer Sterling for help in serotyping; Professor Brian G Spratt for technical advice; and Angela Pollard for typing the manuscript.

1 Austrian R. Some observations on the pneumococcus and on current status of pneumococcal disease and its prevenon current status of pneumococcal

tion. Rev Infect Dis 1981;3:S1-17.
2 Baquero F. Pneumococcal resistance to $\beta$-lactam antibiotics: a global geographic review. Microbial Drug Resistance 1995;2:115-20

3 Liñares J, Alonso T, Pérez JL, Ayats J, Dominquez MA, Pallarés R, Martín R. Decreased susceptibility of penicillinresistant pneumococci to twenty four $\beta$-lactam antibiotics. f Antimicrob Chemother 1992;30:279-88.

4 Klugman KP, Saunders J. Pneumococci resistant to extended-spectrum cephalosporins in South Africa. Lancet 1993;341:1164.

5 Hofmann J, Cetron MS, Farley MM, Baughman WS, Facklam RR, Elliott JA, et al. The prevelance of drug-resistan Streptococcus pneumoniae in Atlanta. $N$ Engl F Med 1995; 333:481-6

6 Pallarés R, Liñares J, Vadillo $M$, Cabellos C, Manresa F, Viladrich PF, et al. Resistance to penicillin and cephaosporin and mortality from severe pneur nia in Barcellona, Spain. N Engl f Med 1995;333:474-80.

7 Caputo GM, Applebaum PC, Liu HH. Infections due to penicillin-resistant pneumococci. Clinical, epidemiologic and microbiologic features. Arch Intern Med 1993;153: 1301-10.

8 McDougal LK, Facklam R, Reeves M, Hunter S, Swenson JM, Hill BC, Tenover FC. Analysis of multiple antimicrobial-resistant isolates of Streptococcus pneumoniae from the United States. Antimicrob Agents Chemother niae from the United
9 Lonks JR, Medeiros AA. The growing threat of antibioticresistant Streptococcus pneumoniae. Med Clin North Am 1995;79:523-35.

10 Whelen AC, Felmlee TA, Hunt JM, Williams DL, Roberts GD, Stockman L, Persing DH. Direct genotypic detection of Mycobacterium tuberculosis rifampin resistance in clinical specimens by using single tube heminested PCR. $\mathcal{F}$ Clin Microbiol 1995;33:556-61.

11 Heym B, Alzari PM, Honore N, Cole ST. Missense mutations in the catalase-peroxidase gene, Kat G, are assomutations in the catalase-peroxidase gene, Kat G, are assolosis. Mol Microbiol 1995;15:235-45.

12 Korten V, Huang WM, Murray BE. Analysis of PCR and direct DNA sequencing of gyr A mutations associated with fluoroquinolone resistance in Enterococcus faecalis. Antimicrob Agents Chemother 1994;38:2091-4.

13 Duka-Malen S, Evers S, Courvalin P. Detection of glycopeptide resistance geneotypes and identification to the species level of clinically relevant enterococci by PCR. $\mathcal{f}$ Clin Microbiol 1995;33:24-7.

14 Tenover FC, Huang MB, Rasheed JK, Persing DH. Development of PCR assays to detect ampicillin resistance Development of PCR assays to detect ampicillin resistance genes in cerebrospinal fluid samples containing H
philus influenzae. $\mathcal{F}$ Clin Microbiol 1994;32:2729-37.

15 Petersson AC, Miorner H. Species-specific identification of methicillin resistance in staphylococci. Eur $\mathcal{F}$ Clin Microbio Infect Dis 1995;14:206-11.

16 Ploy MC, Giamarellou $\mathrm{H}$, Bourlioux $\mathrm{P}$, Courvalin $\mathrm{P}$, Lambert $T$. Detection of aac (6')-I genes in amikacinresistant Acinetobacter spp. by PCR. Antimicrob Agents Chemother 1994;38:2925-8.

17 Rahman M, Mauff G, Levy J, Couturier M, Pulverer G Glasdorff N, Butzler JP. Detection of 4-quinolone resistance mutation in gyr A gene of Shigella dyserteriae type 1 ance mutation in gyr A gene of Shigella dyserteriae type
by PCR. Antimicrob Agents Chemother 1994;38:2488-91.

18 Zighelboim S, Tomasz A. Penicillin-binding proteins of multiply antibiotic-resistant South African of Streptococcus pneumoniae. Antimicrob Agents Chemother 1980;17: $434-42$.

19 Hakenbeck R, Tarpay M, Tomasz A. Multiple changes of penicillin-binding proteins in penicillin resistant clinical isolates of Streptococcus pneumoniae. Antimicrob Agents Chemother 1980;17:364-71.

20 Hakenbeck R, Ellenbrok $H$, Briese $T$, Handwergen $S$, Tomasz A. Penicillin-binding proteins of penicillinsusceptible and resistant pneumococci: Immunological relatedness of altered proteins and changes in peptides carrying the $\beta$-lactam binding site. Antimicrob Agents Chemother 1986;30:533-58.

21 Spratt BG. Resistance to $\beta$-lactam antibiotics mediated by alterations of penicillin binding proteins. In: Bryan LE, ed. Handbook of experimental pharmacology. Berlin: Springer Verlag, 1989:77-100.

22 Dowson CG, Hutchison A, Spratt BG. Extensive remodelling of the transpeptidase domain of penicillin-binding proling of the transpeptidase domain of penicillin-binding protein 2B of a penicillin resistant South African isolates of

23 Laible G, Spratt BG, Hakenbeck R. Interspecies recombinational events during the evolution of altered PBP.2X genes in penicillin-resistant clinical isolates of Streptococcus pneumoniae. Mol Microbiol 1991;5:1993-2002.

24 Martin C, Sibold C, Hakenbeck R. Relatedness of penicillin-binding protein la genes from different clones of penicillin-resistant Streptococcus pneumoniae isolates in pouth Africa and Spain. EMBO f 1992;11:3831-6.

25 Rudolph KM, Parkinson AL, Black CM, Mayer LW. Evaluation of polymerase chain reaction for diagnosis of pneumococcal pneumonia. $\mathcal{F}$ Clin Microbiol 1993;31:2661-6.

26 Issacman DJ, Zhang Y, Wald ER, Wadowsky R, Ehrlich G. A sensitive and specific assay utilizing the polymerase chain reaction for the detection of S. pneumoniae in blood. Pediatr Res 1994;35:182.

27 Hassan-King M, Baldeh I, Secka O, Falade A, Greenwood B. Detection of Streptococcus pneumoniae DNA in blood cultures by PCR. $\mathcal{F}$ Clin Microbiol 1994;32:1721-4.

28 Zhang Y, Isaacman DJ, Wadowsky RM, Rydquist-White J, Post JC, Ehlrich GD. Detection of Streptococcus pneumoniae in whole blood by PCR. F Clin Microbiol 1995;33:596601 .

29 Friedland LR, Menon AG, Reising SF, Ruddy RM, Hassett DJ. Development of a polymerase chain reaction assay to detect the presence of Streptococcus pneumoniae DNA Diagn Microbiol Infect Dis 1994;20:187-93.

30 Gillespie SH, Ullman C, Smith MD, Emery V. Detection of Streptococcus pneumoniae in sputum sample by PCR. $f$ Clin Microbiol 1994;32:1308-11.

31 Isaacman DJ, Zhang Y, Rydquist-White J, Wadowsky RM, Post JC, Ehrlich GD. Identification of a patient with Streptococcus pneumoniae bacteraemia and meningitis by tococcus pneumoniae bacteraemia and meningitis by polymera 601 .

32 Saruta K, Matsunaga T, Hoshina S, Kono M, Kithara S, Kanemoto $S$, et al. Rapid identification of Streptococcus pneumoniae by PCR amplification of ribosomal DNA spacers region. FEMS Microbiol Lett 1995;132:165-70.

33 Ubukata K, Asahi Y, Yarmane A, Konno M. Combinational detection of autolysin and penicillin-binding protein $2 \mathrm{~b}$ genes of Streptococcus pneumoniae by PCR. $\mathcal{F}$ Clin Microbiol 1996;34:592-6.

34 Facklam RR, Washington JA II. Streptococcus and related catalase-negative gram positive cocci. In: Balows A Hausler WJ, Herrmann KI, Isenberg HD, Shadomy HJ, eds. Manual of clinical microbiology. 5th edn. Washingto DC: American Society of Microbiology, 1991:238-57. 
35 National Committee for Clinical Laboratory Standards. Methods for dilution antimicrobial susceptibility tests for Methods for dilution antimicrobial susceptibility tests for
bacteria that grow aerobically. 3rd edn. Vol 13. No 25 . bacteria that grow aerobically. 3rd edn. Vol 13. No 25.
Approved Standard M7-A3. Villanova, PA: National Approved Standard M7-A3. Villanova, PA: Nationa

36 Miles AA, Misra SS, Irwin JO. The estimation of the bactericidal power of the blood. $\mathcal{F H g}$ 1938;38:732-49.

37 Dowson CG, Coffey TJ, Kell C, Whiley RA. Evolution of penicillin resistance in Streptococcus pneumoniae, the role of Streptococcus mitis in the formation of a low affinity
PBP 2b in S. pneumoniae. Mol Microbiol 1993;3:635-43.

38 Ajello GW, Bolan GA, Hayes PS, Lehmann D, Montgomery J, Feeley JC, et al. Commerical latex aggutination tests for detection of Haemophilus influenzae type $b$ and Streptococcus pneumoniae antigens in patients with bacteraemic pneumoniae. F Clin Microbiol 1987;25:1388-91.

39 Barcus VA, Ghanekar K, Yeo M, Coffey TJ, Dowson CG. Genetics of high level penicillin resistance in clinical isolates of Streptococcus pneumoniae. FEMS Microbiol Lett 1995;126:299-304. 